\title{
Tenach and Old Testament - the same Bible?
}

\author{
James Alfred Loader \\ Institut für Alttestamentliche Wissenschaft und Biblische Archäologie \\ University of Vienna \\ Professor Extraordinarius, UNISA
}

\begin{abstract}
This article questions the simplicity with which not only Old Testament specialists, but theologians in general - especially in the Protestant tradition - usually identify the Hebrew text as printed in the Biblia Hebraica Stuttgartensia (and its predecessors) as the "real" Old Testament. The relevant questions are grouped into four clusters: What is meant by "Tenach" and "Old Testament", what is a canon, is the Jewish Tenach continued in the same way as the Christian Old Testament, what are the theological implications of their dissimilarity and their association? An argument is developed in which it is concluded that there are several conditions under which the Tenach of the Jews and the Old Testament of Christians can not be called the same Bible. Only when the canon is seen as a process as opposed to a list or a book, can a positive answer to the question be given. Several advantages of this approach conclude the discussion.
\end{abstract}

The obviousness with which theologians, especially of the Protestant strain, take for granted that they work with the "real" Old Testament canon when they use the Biblia Hebraica Stuttgartensia (and, of course its predecessors) is in need of rethinking. The title of this article is intended to question this assumption, but also some ramifications that go with it. The unity of the Tenach ${ }^{1}$ itself and the Old Testament is also put under a question mark. Whatever the answer or answers to these questions, the very topic of our title question presupposes the possibility that the Tenach and the Old Testament are not the same thing. In this starting point as well as in the two terms it concerns, more is however implied. We shall find that the basic question touches off further questions as we proceed, so that answers raise more questions - somewhat like the old rabbinic

\footnotetext{
1 In the transliteration of the acronym (= Torah, Nebiim and Ketubim) I follow one of several alternatives, among which also are Tanach, Tenak or Tanak.
} 
"midrash" concept of study: one continually seeks answers to ever new questions calling for answers. We shall already see that as soon as we try to clarify what the two designations mean.

\section{WHAT IS MEANT BY "TENACH" AND "OLD TESTA- MENT"?}

At the very first level a complex of questions presents itself. How are the terms used?

- When reference is made on the one hand to the "Tenach", an old and venerated Jewish - as opposed to Christian - term is used to denote the Hebrew canon of an overwhelming majority within the present Jewish community of faith. But this formulation itself presupposes that several canons existed and exist in this community. For one, not only Hebrew canons are used in Judaism. Second, there are different groups and currents within Jewry who have differing views on the canon. And third, these internal variations are historically determined.

- When, on the other hand, reference is made to the "Old Testament", a specific part of the Christian - as opposed to Jewish - canon is meant. This is of course already obvious in the adjective "old": a "New" Testament is to follow the "Old". But also this oldest and largest part of the Christian canon is variegated within the faith communities using it (plural, since it is questionable whether the global religious groups going by the Christian label can be dubbed a single community at all).

- Moreover, the unity of the shape in which the Holy Scripture of Israel/Judaism on the one hand and a part of the Holy Scripture of the church/Christianity on the other present themselves is questioned as well. It is not even evident that the language of the Christian Old Testament is Hebrew. The question leaves room for the possibility that both the Tenach and the Old Testament are inherently differently structured and therefore carry different meanings. 
Since so much is involved with the terminology used in these matters, we shall have to take issue with another question in the labelling business: The controversy as to the name of the first two thirds of the Christian canon. Can one, from a Christian perspective, speak of the "Old" Testament? Does this not imply a religious presupposition or a theological prejudgement, notably that the Old Testament is antiquated and outdated? Logically, the adjective does not necessarily imply this. "Old" does not mean its own superlative, "too old". But when they hear "Old" prefaced to "Testament", people do sometimes seem to detect an emotive aspect reminiscent of inferiority to the effect of suggesting second-tear status in the ranking of the Jewish canon and a part of the Christian one. I don't think this is justified. In accordance with the "Guidelines" of the Vatican Commission for Relations with Judaism (1985) and at variance with those given by the Reformed Church in the Netherlands (1983), I use the designation "Old Testament", venerated since Melito of Sardes (c $180 \mathrm{CE}$ ), and not the proposal "First Testament" as opposed to "Second Testament" for the New, put forward by James Sanders (1987:47-49) and Erich Zenger (1995:145-148.152-154), who have not convinced me of what they regard to be the advantages of the latter. Even if it is granted that the idea of "ancientness" ("Anciennität", as Zenger calls it) can be positively used, Zenger's view requires a pejorative to be heard in the name "Old Testament". This can be countered in a twofold way.

The supposed pejorative connotation to the adjective "old" in the name of the first part of the Christian canon cannot be upheld, at any rate not outside the Euro-American world. On the contrary, in ancient (old!) Israel as well as often elsewhere in Asia, Africa and the rest of the so-called "Third" World it is rather regarded as up- than downgrading to be called "old": the older, the more venerable. A negative association may be possible in the Western world, but is by no means necessary even here. So there is no reason to claim universal validity for it in such a sweeping generalisation.

More importantly, it can be said with equal justification that the qualifications "first" and "second" do not necessarily have to indicate a historical order. They can equally well suggest a depreciation of one relative to the other, for example: the first wins, the next is only second best, first lady, first class, first and foremost, the First World - even if the term was originally intended otherwise - is highly developed, the Third (!) is 
underdeveloped, and so on. A possible suggestion of downgrading the New Testament by means of ordinals is, however, equally unacceptable as a suggested downgrading of the Old by means of other adjectives.

Therefore it can be argued on good grounds that a neutral sequence of the two Testaments can equally well be expressed by means of the adjectives "old" and "new" as by means of numbers "one" and "two". What can be said for historical and theological correctness in the new terminology can also be said for the old. And all that may be dangerous in the old, is not less so in the new. So, nothing is gained by the new terminology. It simply is the second.

\section{THE EXTERNAL FORM OF THE "CANONS"}

If the very names of the parts of the canon already point to their problematic theological nature, then it prompts a further question on another level. What is a canon? The answer given generally is "yardstick" or "norm", which is of course correct in as far as it expresses the original usage of the word. Whether this should be taken to mean that something is regarded as a norm for the faith or was itself accorded canonical status according to a norm (yardstick, criterion) or both, may be disregarded for our present purpose. But the relevant question should be put more precisely: Is a canon a book? Not necessarily. A canon can also exist where there is no book comprising it. This can be demonstrated by an important, if self-evident aspect of our topic. Could a book too voluminous to fit onto one scroll (מגלה) have existed as a single volume in the late preChristian period, when there were no codices? It is hardly thinkable that pre-Christian, that is, pre-codex people would be able to conceive of a large cabinet or cupboard filled with parchments as a single book (cf von Campenhausen 1968:304; Barr 1983:57; Zenger 1995:147, n.169; Loader [2002]). Such a library of scrolls could conceivably have been thought of as a "canon" in the sense of a collection of many books whose titles appear on a list of authoritative writings, but not as a "canon" of collected books (ספרים) on scrolls in the sense of one completed and fixed book. If ספגרות) meant "scroll", therefore

${ }^{2}$ Cf N Lohfink (1995:72) about what he calls the "assertive", "illocutive" and "performative" aspects of a canonical text, and the further argument on "fixing" (1995:73). 
the same as מגללה, and if that was the only known concept of a book, then it is difficult to see how the redactors, transmitters or readers of, say, the Torah or Isaiah scrolls, those of the Twelve Minor Prophets, the Psalter or the Five Megillot could see these together with the others as one formal, unitary book.

The library-like character of these books was preserved even after the introduction of the codex in the first century CE, so that they were transmitted as a number of individual books despite their newly devised binding between the covers of a codex. After having transmitted them as such for centuries, both the Jewish and Christian traditions still speak of 39 (or 22 or 24) and 66 (or more) books respectively. The fact that the Christian tradition could also refer to the Old Testament as $\dot{\eta} \gamma \rho \propto \phi \eta^{4}$, does not alter this in any way. The Masoretic tradition collected detailed and exact data specific to individual books and transmitted these in several ways, among others in colophons at the end of each book. Even if the primary purpose of these labours was to preserve the correct textual form, it confirmed that each book remained a separate ספר notwithstanding all other mutual aspects and qualities shared with the rest.

The names by which the collection goes in both the Jewish and Christian traditions point in the same direction. The acronym תנקך stands for three groups of books indicated by the first letters of each cluster: כתובים and (Toיאים ותורה (Torah, Prophets and Writings). Moreover, if the Christian tradition could parallel the Jewish ת

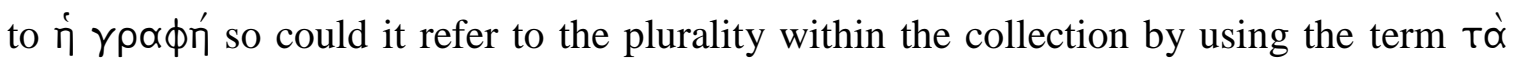
$\beta ı \beta \lambda_{i \alpha}^{\prime} \alpha$, "the books". In both instances the plurality of the books is emphasised.

At the beginning of the canon formation, therefore, stands the concept of a collection or a list of revered books. That would mean that the idea of a common canon in the sense of a final, authoritative book for Jews and Christians during the first period of their co-existence is not even an issue. Neither community had it. But the books in the boxes were later unified by being bound between covers - without which the idea that the collection makes up one single book could never have been conceived of. So, despite all uncertainty and lack of clarity as to their origins, at a certain point it was a fait accompli

\footnotetext{
${ }^{3}$ Kühlewein (1984:166); inscription, document, letter, book; cf Jr 36: 4; Ezk 2:9; Ps 40:8.

${ }^{4}$ Cf Lk 4:21; Jn 2:22; 7:38, 42; Rm 4:3; 9:17; Gl 3:8, 22 etc.
} 
that different book-canons were there. This has considerable consequences, since a bookcanon that has ceased to be only a collection of many books is a literary product.

\section{THE LINES OLD TESTAMENT-NEW TESTAMENT AND TENACH-TALMUD}

A glance at the differing sizes and sequences of the biblical books in the collections named Tenach and Old Testament, and even the contents of a number of them (such as Jeremiah or the Psalms) in some versions, would indeed seem to lead to the inevitable conclusion that they certainly do not make up the same Bible. Add to this that the Old Testament is no longer a unit by itself, but part of a still larger collection and therefore heavily qualified by the new context in which it finds itself since it became the older of two Testaments. Whether all this means that we should regard the two collections as different Bibles or canons $^{5}$, is a different matter altogether.

Certainly the Old Testament is continued in the New as they appear in the Christian Bible (whether there is such a thing as "the" Christian Bible at all, can be left aside for the moment). In its new context it therefore plays a role differing from that played by the Tenach in its context. But the Tenach too has a comparable continuation in rabbinic literature in that the oral Torah, as counterpart of the written Torah, found its expression in the Mishnah and Talmud (cf Zenger 1995:141; Dohmen \& Stemberger 1996:152). Therefore it can be claimed on good grounds that there are two pathways leading from the Tenach and from the Old Testament to their distinct new literary heritages.

These paths already begin in the as yet uncompleted canons. Initially there was a canon in the broad sense consisting of the Torah and the Prophets, whereas the books that were later to be added as the "Writings" were still undefined, in some cases did not even exist, and were in any case judged differently by respectively the Jewish communities in Egypt and their co-religionists in Palestine (cf Dohmen \& Stemberger 1996:146-148). In this way a Jewish corpus was expanded on the one hand via Hebrew (and, what is often forgotten, Aramaic!) "Writings" and on the other hand via Greek translations of the same

${ }^{5}$ See below, $\S 4$, on the canon as a process. 
(and, what is likewise often neglected, writings originally composed in Greek!), so that it became part of a newer, larger, but two-pronged literary body. At least for a major part of "Hebrew" Jewry ${ }^{6}$ the Hebrew collection became a "canon" and, as such, the cornerstone of rabbinic literature, while the larger collection of at least a major part of Hellenistic Jewry became the cornerstone of the Christian tradition, first as a "canon" in its own right and then as the greater part of a new literary corpus that grew out of its own $\operatorname{root}^{7}$. The latter was called тó $\beta ı \beta \lambda_{i}^{\prime} \alpha$, the "Books" = the "Bible", and so gradually became a new "canon" consisting of two Testaments.

In terms suggested by Zenger and Dohmen, this process can indeed be seen as a natural development of two branches from one stem. As opposed to former consensus, it is compatible with more recent opinion that it is no longer tenable to picture the early church as taking over a fixed canon from the Hellenistic Jewish community in Egypt and thereby forcing rabbinic Judaism to polemically reject this facet of the Jewish tradition (Hengel \& Deines 1994:183). These considerations mean that the common root of Judaism and Christianity in the literary heritage of Israel is not only a matter of a common stock of books (albeit differently arranged), but also of a common way of handling them in the process. Nevertheless two diverse canons in the sense of completed book collections eventually did emerge from this canonical process. Under these historical circumstances the two canons naturally were respectively of the Hebrew/Palestinian and the Septuagint/Egyptian types. These are literary products, and as such have their own distinct shape because each has its own structure and partly differing contents. Since literary structure contributes to the meaning of a text, this de facto situation has theological relevance. Therefore we must next consider the cluster of questions related to this fact.

\footnotetext{
${ }^{6}$ Cross currents, such as the Sadducee and Samaritan traditions, Qumran, the Karaite movement, important as they are, are left unconsidered for the purposes of the present argument, since the mainstream rabbinic tradition interests us here.

${ }^{7}$ However, this did not happen without controversy, as the later difference between Jerome, who defended the Hebrew tradition, and Augustine, who took sides with the Alexandrian tradition vividly illustrates (Hennings 1994:217).
} 


\section{THE THEOLOGICAL RELEVANCE OF JEWISH AND CHRISTIAN CANONS}

At this point we find, generally speaking, two communities of faith, each with its own collection of sacred writings regarded and read as one book ${ }^{8}$. This brings to light a further link in our chain of questions: Does the use of the Tenach or the Old Testament, as the case may be, as one book presuppose a canon? The answer is obviously affirmative, since in both cases the single book presents itself as a unitary religious or theological standard. Therefore the presupposed canon is no longer only a canon in the sense of an authoritative index, but above all in the sense of a completed text. Both the Tenach and the Old Testament, then, became available canons of the latter type. Since our present concern is the relationship of the Tenach and the Old Testament, we are only interested in their origin as far as this highlights what they have in common. Therefore we shall not occupy ourselves here with aspects as the difference between "authority" as the beginning and "canonicity" as the result of the development". Even if canonising in both cases came about only gradually, it is important from our perspective that this process was complete at a certain point. We cannot pin down a moment, but we can say at which point it had already been reached. When, at the end of the first century CE, it was important to Flavius Josephus ${ }^{10}$ to define the precise number of 22 books (plural!) as accurately as possible, this point had already been passed.

It can be argued that the canon is to be read in the light of the authority of the prophets $^{11}$; the fact that, from this perspective, Moses had to be presented as a prophet so

\footnotetext{
8 Of course various forms of the two canonical books existed in both communities, so that we should strictly be speaking of several rather than two such unitary "books". However, since the end of the first century CE two of these prevailed in the sense just described (cf §3) as the main currents of the ever continuing tradition.

9 The rejection of the thesis is accepted widely by earlier scholars (that a so-called rabbinic synod in Jamnia fixed the canon) (cf Schäfer 1975:116-124). The same can be said of the doubtful existence of an "Alexandrian canon" (cf Hanhart 1984:400), and of the defence of a Jewish canon with Greek sequence but Hebrew numbers as by Flavius Josephus (cf for example, the general review in Barr (1983:49-74; also Sundberg 1964).

${ }^{10}$ Contra Apionem I, 37-42; further, Loader [2002].
}

11 So Dohmen \& Stemberger (1995:153). Cf R Rendtorff (1991:68-69), who - with reference to the development of this thesis by J Blenkinsopp (1977) - speaks of a "mutual relationship" and even of the "tension between Torah and prophecy". Cf also Loader [2002]. 
as to accord the Torah/Pentateuch its paramount importance (cf Dt 18:15; 34:10), only confirms the position of the Pentateuch. The reciprocal relationship between it and the Prophets is similar in the Tenach and in the Old Testament. In both cases the former is the foundation of the latter and the latter the application of the former. But the application itself is decidedly different in the two canons. Let us begin by considering the so-called Historical Books as they appear in the Old Testament.

- Here several books from the third division of the Tenach stand in the second division of the Old Testament. Ruth, 1 and 2 Chronicles, Ezra, Nehemiah and Esther have been arranged to appear at their appropriate points on the story line of Israel's history: Ruth, as a story from the period of the Judges, appears between Judges and the stories about the end of that period in 1 Samuel, which obviously enhances its meaning for the Davidic dynasty (cf Ruth 4:18-22). The two Books of Chronicles follow 1 and 2 Kings as a repetition of that history from another perspective, which eliminates the "problem" of the Tenach's inverted order, where the Chronicles stand after books describing later times. Ezra and Nehemiah follow to tell the story of the reestablishment of Israel and the rebuilding of its institutions after the exile (suggesting that Ezra was followed by Nehemiah and not vice versa). Esther describes the situation of Jews in the Persian diaspora. So the order of books here suggest consciousness of a connected line of events in Israel's past as viewed from a late exilic or post-exilic perspective. The picture is amplified when the addition of so-called deuterocanonical books, such as Tobit, Judith and the Books of the Maccabees is drawn into the calculation (not to mention those books with additions, such as, among others, the Additions to Esther, that do not appear in the Tenach). These books focus on the past as opposed to the "poetic" books who concern themselves with wisdom and other issues for the present.

- In the Tenach the picture is completely different. The "historical" books mentioned are either subsumed in the third division of the canon or are missing altogether. The story line reaches the fall of Jerusalem and, apart from a short 


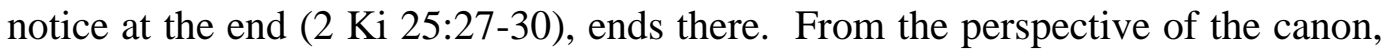
this focuses attention on the fall. Since the prophets also hinge on this point, the books named after them as well as those describing Israel's history have the same orientation. Therefore they can all of them be regarded as prophetic books. This is exactly what happened in the Hebrew tradition. The historical books are prophetic, applying as they do the same norm as the prophets, notably the will of God as given in the Torah. Therefore they are called the "Former" and the "Latter Prophets". So they together show that the great pre-exilic prophets were correct in their criticism of Israelite/Judean society: Israel's history is the tragic story of God and his people.

- Returning to the Old Testament, the prophets follow only in the fourth position, after the books on the past and the present. Part of this division is a fourth prophetic book inserted between Ezekiel and the Twelve Minor Prophets, the apocalyptically influenced Book of Daniel. This comes as no surprise, since the prophets are here treated as people who foretell the future ${ }^{12}$ and as such fit quite well with the apocalyptic preoccupation with the future. This is how early Christianity used the prophets, which is evidenced among other things by their use in the New Testament as Messianic proof texts and confirmed by the position of the Apocalypse of John in the New Testament, where the fourfold sequence of the Old Testament is emulated (Gospels, acts of the early church, instructions for present life, apocalypse for the future).

The position of Dohmen is somewhat different (Dohmen \& Stemberger 1996:153). According to him the Old Testament is organised from a "prophetic perspective", which is to be contrasted with a "Torah-perspective", found in the Tenach. In the former the whole line of reception finds its point of departure in "prophecy". It seems to me that Dohmen intends this to refer to the books Isaiah to Malachi, since "prophecy" in his context does not mean the phenomenon, but a canonical collection. As

${ }^{12}$ Naturally this is also an aspect of the Hebrew perspective, but certainly not a dominating motif (which also goes for the pre-exilic prophecy itself). 
opposed to this, the "Torah-perspective" is supposed to be found where everything takes its orientation from the Torah.

But this is unlikely for three reasons: For one, the two "orientations" do not exclude each other, and Dohmen's proposal cannot do justice to the strong Torahorientation of the prophets themselves ${ }^{13}$. Second, in order to uphold the supposed bipartite schema "Torah-Nebiim", it becomes necessary to assume that the large number of "Writings" was (at least initially) built into the prophetic collection. But this is not attested in the tradition. Third, it becomes difficult to explain how the emulation of a fourfold canon in the New Testament ${ }^{14}$ can be squared with the fact that the "historical books" as a group disappears in Dohmen's thesis ${ }^{15}$. Every "prophetic perspective" is itself also a "Torah-perspective". The variations in orientation therefore have nothing to do with varying foci on either the Torah or the Prophets, but in varying understandings of what prophecy essentially is: interpretation of the present or prediction of the future.

In the Tenach prophecy and the account of history are identified, brought together under the heading "Prophets" and therefore represent the view that prophecy is the analysis of historical reality by the prophetic norm. And this is the Torah. In the Septuagint the prophets follow after the books recounting the past and those containing advice, prayers and reflections for the present and thus embody a different understanding of prophecy, notably that it is about the future. Prophets foretell what is to come. Since the early church made the Septuagint its Bible, this alternative understanding became immensely influential in Christianity. The use of the prophetic books as scriptural proofs for the truth of the Christian faith eloquently testifies to this importance. But also the design of the New Testament according to the model of the Septuagint bears witness to the same. So the Septuagint, both as Jewish book (or, which would be safer to say, collection) and as Christian Old Testament (which it gradually became), is a work that

13 Cf Jr 5:4-5; 8:8; 9:13; 16:11; 32:23; Hs 4:6; 8:1; Am 2:4; Hab 1:4; Zph 3:4; cf also Is 1:17, 21, 27; 5:7; 10:1-2; Am 5:7; 6:12; Mi 3:1, 9; 6:8; 7:3 etc.

14 Gospels: Basic revelation in Christ; Acts: past; epistles: prescriptions for life in the present world; Apocalypse: the church's expectations for the future (on this, cf Zenger 1998:31-35).

15 A fourth objection may be that this view does not account for the fact that the "Torah-perspective" found in the Tenach (which is allegedly to be understood as the counter-pole to the "prophetic perspective") draws the "historical" books into the prophetic collection and therefore understands them from this angle. 
proclaims what should be and what is to come. Consistency requires the same to be said of the rather Josephus-like hybrid which became the Protestant canon, where a mixture of the Tenach list and the Septuagint structure were taken over.

In my opinion these observations are theologically significant. However, their application depends on the condition that the de facto diversity of canons under the names "Tenach" or "Old Testament" be respected. The assortment of Jewish traditions concerning the sequence of the Latter Prophets ${ }^{16}$ has its counterpart in a variety of Orthodox, Roman Catholic and Protestant traditions. In the light of so many canons in both Judaism and Christianity, the very question whether "the" Jews and "the" Christians have the same canon seems to lose its topicality. Although only a few have asserted themselves quantitatively and in time, the question still remains valid in principle. The debate about a new arrangement of the canon ${ }^{17}$ has recently become topical again as it was during the Reformation and in the history of the church and Judaism generally. In the context of this fact I think it quite possible to regard the Tenach and the Old Testament as one phenomenon and therefore as "the same" if we are prepared to accept that the canon is a process. The "Tenach" and the "Old Testament" would then each be a religious manifestation of this one phenomenon. This brings us to the last part of my considerations: dealing theologically with multifarious shapes of a book that is actually more than one book.

\section{ONE BIBLE IN MUTUALLY COMPLEMENTING AND LIMITING CANONS}

So, do Jews and Christians then have the same Bible or not? -

- No, if the canon is seen as a list or table of contents.

- No, if it refers to differently structured book collections.

\footnotetext{
16 In the Talmud: Jeremiah, Ezekiel, Isaiah, the Twelve Minor Prophets (Dodekapropheton); Manuscripts from the German and French tradition: Jeremiah, Isaiah, Ezekiel, the Twelve; Manuscripts from the Spanish tradition as well as the Masoretic Texts: Isaiah, Jeremiah, Ezekiel, the Twelve.

17 Cf Zenger (1995:179), who refers to H-G Link (1988:83-96).
} 
- No, if the monopolizing of the Tenach or some hazy identification of it with the Old Testament is meant.

- $\quad$ Yes, if the canon is seen as a process with ecumenical implications incorporating Christians as well as Jews.

This "yes" does not imply new organization of the canon, nor does it in principle preclude a new reformation or new Jewish-Christian relations. But theologically it can be very fruitful. Three examples should illustrate this:

First, we may again consider the different understandings of prophecy referred to above. Without narrowing prophecy down to a form of fortune telling or to a scheme of promise and fulfillment, the fact that it does also have a concern for the future cannot be denied. Future prospects and the intention of surviving in the future are already present in the Pentateuch. But the emphasising, indeed the centralisation of the predicting side of prophecy in the Jewish Septuagint, that is, in the christianised Bible, creates a new perspective of hope. From this perspective hope becomes the hermeneutical horizon for reading the Bible, a kind of key for understanding Scripture that emanates from a specific understanding of prophecy based on the Pentateuch. But this view is both limited and complemented by the Tenach's understanding of prophecy: We do not only need the prospect of the future, but also the willingness to accept responsibility for the present. We cannot dispense with the Hebrew understanding of prophecy as analysis of this world, as criticism and a call to repentance in the present where God's people live. For this understanding works with both poles around which the message of the Torah is built: God's demand of righteousness and his forgiving mercy (cf Loader 2001:1-16). In this sense the Torah is not only a formal principle for the structuring of the prophetic message, but also the deepest principle of its content. And that of the rest of the Bible. I submit that both perspectives are valid for both communities of faith. Both of them need both.

The second manifestation of the theological fruitfulness of affirming a common "process canon" relates to a paradoxical failure of Israel - but, emphatically, not a failure or breakdown in the sense of Rudolf Bultmann's "Scheitern". What I mean, is the following: The very catastrophe of Israel, the fact that the prophetic analysis and 
interpretation of Israel's history had been correct, as reflected in both the Latter Prophets and the Torah's view of Israel as an obstinate people, enabled this people to survive. The self-critical reflection to be seen in the redaction of the Tenach, notably that Israel brought the exile upon itself as a result of its disobedience to God, called it into being as the Jewish people. Neither powerlessness on God's part nor any rejection of his people by him is an option - only the acknowledgement of the people's own failure. The structuring of the Torah therefore is simultaneously the sealing of the prophetic understanding of God's righteousness according to the standard of the Torah and a call to repentance and hope. That is why there is a Tenach. That is why there is a Jewish people. Life has sprung from defeat. I think that this basic structure of the Tenach can also be detected without the help of the christianised Septuagint in the message of Jesus: Life, future and hope out of defeat (cf Loader 1975: passim).

The third manifestation can be short. Perhaps the hybrid canon of the Reformation, an Old Testament with Hebrew content but Greek arrangement may not be such a mongrel after all. Perhaps it should rather be understood as a step towards rapprochement between Jews and Christians who then do share a common Bible.

\section{Works consulted}

Barr, J 1983. Holy Scripture: Canon, authority, criticism. The Sprunt lectures delivered at Union Theological Seminary, Richmond, Virginia, February 1982. Oxford: Clarendon Press.

Barton, J J, Exum, C \& Oeming, M (Hrsg) [2002]. Das Alte Testament und die Kunst. (Gerhard von Rad memorial volume, forthcoming).

Blenkinsopp, J 1977. Prophecy and Canon: A contribution to the study of Jewish origins. Notre Dame: University of Notre Dame Press. (University of Notre Dame Center for the study of Judaism and Christianity in Antiquity 3.)

Dohmen, C \& Söding, T (Hg) 1995. Eine Bibel - zwei Testamente: Positionen Biblischer Theologie. Paderborn/München/Wien/Zürich: Ferdinand Schöningh. (UTB 1893.) 
Dohmen, C \& Stemberger, G 1996. Hermeneutik der jüdischen Bibel und des Alten Testaments, Stuttgart. Kohlhammer. (Kohlhammer-Studienbücher Theologie 1, 2.)

Hanhart, R 1984. Die Bedeutung der Septuaginta in neutestamentlicher Zeit. ZThK 81, 395-416.

Hengel, M \& Deines, R 1994. Die Septuaginta als "christliche Schriftensammlung", ihre Vorgeschichte und das Problem ihres Kanons, in Hengel \& Schwemer 1994:182284.

Hengel M \& Schwemer, A M (Hrsg) 1994. Die Septuaginta zwischen Judentum und Christentum. Tübingen: J C B Mohr.

Hennings, R 1994. Der Briefwechsel zwischen Augustinus und Hieronymus und ihr Streit um den Kanon des Alten Testaments und die Auslegung von Gal. 2, 11-14. Leiden: Brill.

Kühlewein, J 1984. s v סֶּ sefar Buch. THAT 2.

Link, H-G 1988. Der Kanon in ökumenischer Sicht. JBTh 3, 83-96.

Loader, J A 1975. Aspekte van menslike mag in die Ou Testament. Groningen: Rijksuniversiteit Groningen.

Loader, J A 2001. "Law and Gospel" in the Pentateuch organisation. HTS Theological Studies 57, 1-16.

Loader, J A [2002]. Das Alte Testament - ein Geschichtsbuch?, in J Barton, C Exum \& M Oeming (Hrsg), Das Alte Testament und die Kunst. (Gerhard von Rad memorial volume, forthcoming).

Lohfink, N 1995. Eine Bibel - zwei Testamente, in Dohmen \& Söding 1995:71-81.

Sanders, J A 1987. First Testament and Second. Biblical Theology Bulletin 17, 47-49.

Schäfer, P 1975. Die sogenannte Synode von Jabne: Zur Trennung von Juden und Christen im ersten/zweiten Jh. n.Chr. Judaica 31, 54-64.116-124.

Sundberg, A C 1964. The Old Testament of the Early Church: A study of canon. Cambridge: Harvard University Press.

Rendtorff, R 1991. Kanon und Theologie: Vorarbeiten zu einer Theologie des Alten Testaments. Neukirchen-Vluyn: Neukirchener Verlag. 
Von Campenhausen, H 1968. Die Entstehung der christlichen Bibel. Tübingen: Mohr. (Beiträge zur Historischen Theologie 39.)

Zenger, E 1995. Das Erste Testament: Die jüdische Bibel und die Christen. 5.Aufl. Düsseldorf: Patmos Verlag.

Zenger, E 1998. Einleitung in das Alte Testament. 3., neu bearb u. erw. Aufl. Stuttgart: Kohlhammer. (Kohlhammer-Studienbücher Theologie 1,1.) 